\title{
The contribution of protozoa to the protein entering the duodenum of sheep
}

\author{
BY D. G. HARRISON \\ Department of Agricultural Biochemistry, University of Newcastle upon Tyne, \\ Newcastle upon Tyne NEI $7 R U$ \\ AND D. E. BEEVER AND D. F. OSBOURN \\ The Grassland Research Institute, Hurley, Maidenhead, Berkshire SL6 ${ }_{5} L R$
}

(Received 24 May 1978 - Accepted 15 September 1978)

I. Four sheep, each fitted with a rumen fistula and a re-entrant cannula at the proximal duodenum were fed a semi-purified diet containing urea as the only nitrogen source. The quantities of total protozoal amino acid-N (TPAN) present in the rumen and entering the duodenum were determined when the mean rumen dilution rate (D) was low $(0.034 / \mathrm{h})$ and when $\mathrm{D}$ was increased to $0.078 / \mathrm{h}$ by the intraruminal infusion of artificial saliva.

2. Increasing the dilution rate had no significant effect upon the proportions of TPAN present in the total microbial amino acid-N (TMAN) of the rumen fluid and duodenal digesta. With both dilution rates the mean proportion of TPAN in the duodenal TMAN $(0.24)$ was markedly less than the equivalent proportion $(0.45)$ found in the rumen fluid.

3. The daily flow of TPAN, as measured at the duodenal cannula at both dilution rates was equivalent to only $41 \%$ of the flow of TPAN as predicted from measurements of rumen outflow, indicating that a substantial proportion of rumen protozoal protein was retained within the rumen.

Rumen fluid usually contains relatively large numbers of protozoa (Hungate, I966) but relatively little information is available concerning the nutritional significance of the protozoal protein leaving the rumen and entering the small intestine. Abe \& Kumeno (1973) found evidence of sequestration of protozoa within the rumen, and Weller \& Pilgrim (1974) showed that protozoa can be selectively retained within the rumen and estimated that the protozoal nitrogen entering the small intestine of sheep fed on a forage diet comprised only $2 \%$ of the dietary $\mathrm{N}$.

If protozoa are retained within the rumen it would seem likely that the extent of retention might be influenced by the rumen dilution rate (D) which can be increased in vivo by the intraruminal infusion of artificial saliva (Harrison et al. 1975). In this present experiment the influsion technique was used to alter $\mathrm{D}$, and the quantities of protozoal $\mathrm{N}$ flowing from and retained within the rumen were measured in sheep with a normal and an increased rumen dilution rate. Results from this experiment relating changes in $\mathrm{D}$ with alterations in rumen fermentation pattern have been previously published (Harrison et al. 1976).

\section{EXPERIMENTAL}

\section{Animal management}

Four mature wether sheep weighing 45-55 $\mathrm{kg}$ were used in this experiment. Each was fitted with a fistula into the rumen and a re-entrant cannula at the proximal duodenum (Brown et al. 1968). The animals were housed in metabolism cages in a controlled environment under continuous lighting, fed twenty-four equal meals at hourly intervals (Minson, I966), and allowed access to water at all times. The composition of the semi-purified diet is given in Table I. Each animal was offered $637.5 \mathrm{~g}$ food dry matter (DM)/d, which provided a daily intake of 10.79 and $0.13 \mathrm{~g} \mathrm{~N}$ and total amino acid-N (TAN) respectively; food refusals, if any, were recorded daily at 09.00 hours. Each sheep received $3 \mathrm{~g}$ paper impregnated with 
Table I. Composition $(\mathrm{g} / \mathrm{kg})$ of the semi-purified diet

$\begin{array}{lrll}\text { Starch } & 573 & \text { Molassine meal } \ddagger & 59 \\ \text { Cellulose } \dagger & 251 & \text { Corn oil } \$ & 32 \\ \text { Urea } & 35 & \text { Mineral-vitamin mix } \| & 50\end{array}$

† Solka-Floc, grade 50 (Johnson, Jorgensen \& Wettre, London).

$\ddagger$ Molassine Co. Ltd, Tunnel Avenue, London.

$\S$ Mazola maize oil.

|| Contained $\left(\mathrm{g} / \mathrm{kg}\right.$ diet) : $\mathrm{Ca}\left(\mathrm{HPO}_{4}\right) \cdot 2 \mathrm{H}_{2} \mathrm{O}{ }_{14} \cdot 69, \mathrm{~K}_{2} \mathrm{SO}_{4} 13 \cdot 56, \mathrm{NaCl} 12 \cdot 70, \mathrm{Na}_{2} \mathrm{SO}_{4} 5 \cdot 29, \mathrm{MgO} 2 \cdot 07$, also (mg/kg diet); $\mathrm{FeSO}_{4} .7 \mathrm{H}_{2} \mathrm{O} 9 \mathrm{IO}$, choline $475, \mathrm{ZnO} 90, \mathrm{MnO}_{90}, \mathrm{CuSO}_{4} .5 \mathrm{H}_{2} \mathrm{O} 70$, KI 20, nicotinic acid $20, \mathrm{Na}_{2} \mathrm{SeO}_{4} 5, \gamma$-tocopherol 4 , retinol $2 \cdot 4$, thiamine $\mathrm{I} \cdot 36$, riboflavin $\mathrm{I} \cdot 2$, cholecalciferol $0 \cdot 02$, cyanocoba amin 0.02 .

chromic oxide (Corbett et al. 1960) via the rumen fistula at 09.00 hours and a further $3 \mathrm{~g}$ at I6.00 hours each day. They were maintained on the appropriate diet or treatment for at least $2 \mathrm{I} \mathrm{d}$ before any experimental measurements which were made only when the animals were consuming all their food.

\section{Procedure}

Duodenal digesta was collected using the method of MacRae \& Armstrong (1969) as modified by Beever et al. (1971), and the relative proportions of food and microbial protein in the digesta was measured by the ${ }^{35} \mathrm{~S}$ method of Beever et al. (1974). In this latter procedure the specific activity of the methionine in the whole duodenal digesta was compared with the specific activity of the methionine in a 'microbial' fraction isolated from the digesta. Bacteria were isolated from rumen fluid using the techniques described by Hutton et al. (I97I), and rumen volume (RV) and dilution rate were measured using the method of Harrison (1974). Daily samples of rumen fluid (approximately one litre) were taken for seven successive days; approximately $15 \mathrm{ml}$ of this fluid was used for a protozoal count (Boyne et al. 1957) and a further sub-sample of approximately $200 \mathrm{ml}$ was retained and stored at $-4^{\circ}$ until required for analysis. The remaining rumen fluid was returned to the rumen. When all the previously mentioned experimental observations were completed the animals were infused intraruminally with artificial saliva (McDougall, 1948) at the rate of 4 1/d (Harrison et al. 1975) and the experimental observations were repeated.

\section{Chemical methods}

Samples of rumen bacteria, duodenal digesta and rumen fluid were lyophilized and analysed, as appropriate, for $\mathrm{N}$, using the Kjeldahl method, TAN (Harrison et al. 1973) and 2,6diaminopimelic acid-N (DAPN) using the method of Mason \& White (I97I). DM content was determined by heating in an oven at $102^{\circ}$ for $24 \mathrm{~h}$. All samples of duodenal digesta were analysed for $\mathrm{Cr}_{2} \mathrm{O}_{3}$ (Stevenson \& de Langen, 1960) and the values used to correct the daily flow of digesta to $100 \%$ recovery of $\mathrm{Cr}_{2} \mathrm{O}_{3}$ (MacRae \& Armstrong, I969).

\section{Statistical analysis}

Analysis of variance was performed on the results and animal and treatment effects were isolated. Although periods and treatments were totally confounded, previous experience has shown that the effects on mature sheep during the period of treatment were small and so all treatment-period effects were assumed to be the result of the imposed treatment only. 


\section{RESULTS}

The flow of $\mathrm{N}$ and TAN entering the duodenum were significantly $(P<0.0 \mathrm{I})$ increased by the intraruminal infusion (Table 2). With both treatments there was a high proportion of total microbial amino acid-N (TMAN) in the TAN entering the duodenum (over-all mean 0.980 ). Assuming that the small quantity of food amino acid-N consumed was completely degraded in the rumen, the difference between the flow of TAN and TMAN was attributed to the $\mathrm{N}$ of endogenous secretion. The infusion also induced a more than twofold increase $(P<0.00 \mathrm{I})$ in $\mathrm{D}$ (Table 2$)$ and significantly reduced both rumen protozoal numbers $(P<0.05)$ and the concentration of TAN in the rumen fluid $(P<0.001)$. Rumen volume was not apparently altered by the infusion.

The proportion of DAPN in the TAN of duodenal digesta, rumen bacteria and rumen fluid was not significantly altered by the infusion (Table 3 ). With both treatments the mean proportion of DAPN in the TAN of rumen bacteria (over-all mean 0.0 II 7 ) significantly $(P<0.001)$ exceeded the equivalent proportion in the duodenal digesta $(0.0087)$ which, in turn, significantly $(P<0.001)$ exceeded the mean proportion in the rumen fluid $(0.0064)$. These values were used in the following equations to calculate the proportion of total bacterial amino acid-N (TBAN) in the TAN of rumen fluid (Table 3) using the assumption that diaminopimelic acid is present in bacteria and absent from protozoa (Synge, 1953; Ling \& Buttery, 1978). The equations also assume that the proportion of DAPN in the TAN of bacteria in the rumen is the same as the equivalent proportion in bacteria entering the duodenum. DAP is a component of the bacterial murein sacculus, which also contains $\mathrm{N}$ acetyl glucosamine (Martin, I966), and repeated analysis of digesta in this experiment showed that the molar ration of DAP : $N$ acetyl glucosamine (mean ratio I : 19) was virtually identical in rumen bacteria and duodenal digesta. This finding indicated that little, if any, degradation of DAP occurred between rumen and duodenum.

$\begin{gathered}\text { Proportion of TBAN in } \\ \text { TAN of rumen fluid }\end{gathered}=\frac{\text { proportion of DAPN in TAN of rumen fluid }}{\text { proportion of DAPN in TAN of rumen bacteria }}$.

The proportions of TBAN in the TAN entering the duodenum were similarly calculated from the next equation (see Table 3):

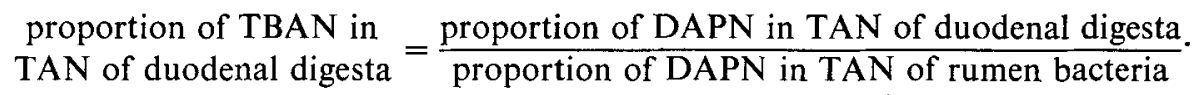

With both treatments the proportion of TBAN in the TAN of duodenal digesta (over-all mean 0.745$)$ markedly exceeded the equivalent over-all mean for rumen fluid $(0.552)$.

If TPAN is considered to represent TMAN less TBAN then the results in Table 3 indicated a retention of protozoal $\mathrm{N}$ within the rumen and it seemed appropriate to calculate the quantities retained. This was achieved by comparing the values for the flow of TMAN, TBAN and TPAN predicted from measurements of ruminal outflow with the values actually obtained by direct duodenal measurement. The appropriate values from Tables 2 and 3 were used in the following equations to calculate values for the predicted and actual duodenal flow $(\mathrm{g} / \mathrm{d})$ of TMAN, TBAN and TPAN which are shown in Table 4 . The use of these equations assumes that rumen bacteria leave the rumen in the liquid phase, and not in association with the solid phase (Hungate et al. 197I). This assumption is based on the findings of a preliminary trial in which three sheep with re-entrant cannulas were fed the same purified diet and defaunated with di-octyl sulphosuccinate (Beever et al. 1974). Measurements of TAN in the rumen liquor, rumen dilution rate and duodenal flow of TAN allowed a direct comparison of the predicted and actual flow of TAN into the duodenum. The mean predicted flow for the three animals was $98 \pm 4 \%$ of the actual flow, indicating, with this 
Table 2. The effect of an intraruminal infusion of artificial saliva $(4 l / d)$ upon the quantities of nitrogen, total amino acid-N (TAN), total microbial amino acid-N (TMAN), and secretion $N$ entering the proximal duodenum of sheep fed on the semi-purified diet $\uparrow$; with values for the proportion of TMAN in the TAN, and for rumen volume, rumen dilution rate, rumen protozoal numbers and the concentration of TAN in the rumen fluid

(Mean values from four animals)

\begin{tabular}{|c|c|c|}
\hline Treatment & Control & Infused \\
\hline \multirow{2}{*}{$\begin{array}{l}\text { Duodenal flow }(\mathrm{g} / \mathrm{d}) \text { of } \mathrm{N} \\
\text { Duodenal flow of TAN }\end{array}$} & II $\cdot 84$ & $13 \cdot 16$ \\
\hline & $8 \cdot 76$ & $9 \cdot 83$ \\
\hline & 0.983 & 0.976 \\
\hline Duodenal flow $(\mathrm{g} / \mathrm{d})$ of TMAN & $8 \cdot 61$ & 9.59 \\
\hline Secretion $N$ & 0.15 & 0.24 \\
\hline Rumen volume (l) & $4 \cdot 89$ & $4 \cdot 78$ \\
\hline Rumen dilution rate $/ \mathrm{h}$ & 0.034 & 0.078 \\
\hline Rumen protozoal numbers $\left(\times 10^{3}\right) / \mathrm{ml}$ & 538 & 395 \\
\hline $\begin{array}{l}\text { Concentration of TAN in rumen fluid } \\
(\mathrm{g} / \mathrm{l})\end{array}$ & $3 \cdot 00$ & $1 \cdot 46$ \\
\hline $\begin{array}{l}\text { NS, not significant } \\
{ }^{*} P<0.05,{ }^{* *} P<0 \cdot 0 \mathrm{I}, \\
\dagger \text { For details of feedin } \\
\pm \text { Pooled SEM derived }\end{array}$ & anal & $\begin{array}{l}\text { Table } \\
\text { ance. }\end{array}$ \\
\hline
\end{tabular}

Table 3. The effect of an intraruminal infusion of artificial saliva $(4 l / d)$ on the proportions of 2, 6-diaminopimelic acid-N $(D A P N)$ in the total amino acid-N $(T A N)$ of the duodenal digesta, rumen bacteria and rumen fluid obtained from sheep fed on the semi-purified diet $\dagger$; with values for the proportion of bacterial amino acid-N $(T B A N)$ in the TAN of rumen fluid and duodenal digesta

(Mean values from four animals)

$\begin{array}{lccc}\text { Treatment } \ldots & \text { Control } & \text { Infused } & \text { SEM } \ddagger \\ \text { Proportion of DAPN in TAN of } & & & \\ \quad \text { Duodenal digesta } & 0.0089 & 0.0084 & 0.00010 \text { NS } \\ \text { Rumen bacteria } & 0.0124 & 0.0109 & 0.00026 \text { NS } \\ \text { Rumen fluid } & 0.0064 & 0.0064 & 0.00014 \text { NS } \\ \text { Proportion of TBAN in TAN of } & & & \\ \quad \text { Rumen fluid } & 0.516 & 0.587 & 0.0291 \text { NS } \\ \text { Duodenal digesta } & 0.718 & 0.771 & 0.0684 \text { NS }\end{array}$

NS, not significant.

$\dagger$ For details of feeding regimen, see p. 521 and Table $\mathrm{I}$.

$\ddagger$ Pooled SEM derived from the analysis of variance.

particular diet, that bacteria left the rumen in the liquid phase. This was presumably due to the nature of the diet, which contained relatively little fibre and was finely ground.

Predicted flow of TAN $=\mathrm{RV} \times \mathrm{D} \times 24 \times$ concentration of TAN in rumen fluid, predicted flow of TMAN = predicted flow of TAN - flow of secretion $N$,

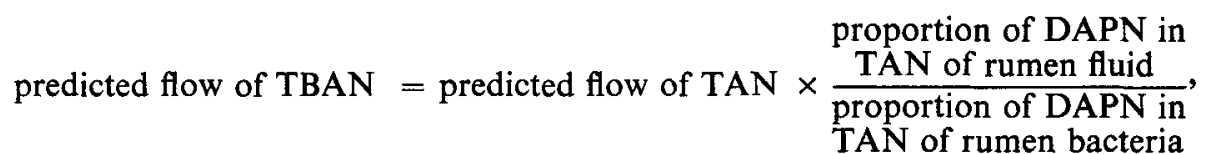

predicted flow of TPAN = predicted flow of TMAN-predicted flow of TBAN, 


$$
\text { actual flow of TBAN = actual flow of TAN } \times \frac{\begin{array}{c}
\text { proportion of DAPN in TAN } \\
\text { proportion of DAPN in TAN } \\
\text { of rumen bacteria }
\end{array}}{\text {, }}
$$

actual flow of TPAN = actual flow of TMAN - actual flow of TBAN.

Table 4. The predicted and actual duodenal flows $\dagger$ of total microbial amino acid-N(TMAN), total bacterial amino acid-N (TBAN) and total protozoal amino acid-N (TPAN) obtained with and without the intraruminal infusion of artificial saliva $(4 / / d)$ in sheep fed on the semipurified diet $\ddagger$

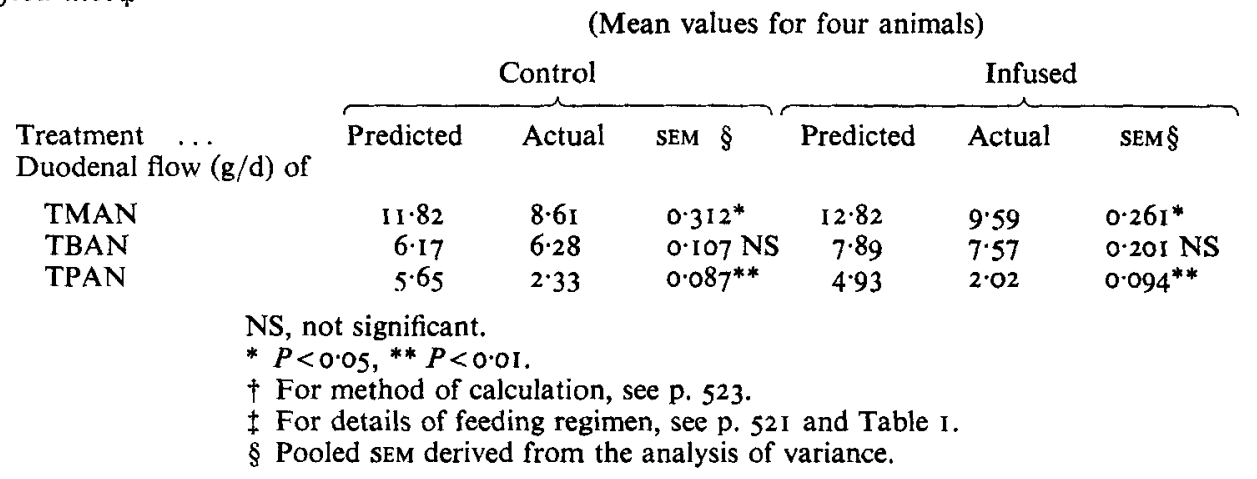

With both treatments the values for the predicted duodenal flow of TMAN and TPAN significantly exceeded the comparable values for actual flow. In contrast, the values for the predicted and actual duodenal flow of TBAN for a given treatment were in close agreement.

With the control diet the actual duodenal flow of TPAN was $2.33 \mathrm{~g} / \mathrm{d}$. This value was only $0.4 \mathrm{I}$ of the predicted flow, indicating that 0.59 of the rumen protozoal protein was retained within the rumen. The comparable value for protozoal retention with the infusion treatment was also 0.59 .

\section{DISCUSSION}

In this present experiment the over-all mean contribution of secretion amino acid- $\mathrm{N}$ to the TAN entering the proximal duodenum was $0.2 \mathrm{~g} / \mathrm{d}$. This finding is similar to that of BenGhedalia et al. (I978) who found that the secretion of pepsin $\mathrm{N}$ in the abomasum of sheep was only approximately $0.05 \mathrm{~g} / \mathrm{d}$. In contrast Clarke et al. (1966) found that the daily abomasal secretion was $2.0 \mathrm{~g} \mathrm{~N}$ and Harrop (I974) estimated that sheep abomasal secretion was between $0.5 \mathrm{I}$ and $2.86 \mathrm{~g} \mathrm{~N} / \mathrm{d}$. The findings of this experiment and those of Ben-Ghedalia et al. (1978) suggest that a large proportion of abomasal secretion may be in a non-protein form as it enters the small intestine.

Hutton et al. (1971) analysed rumen bacteria for DAP and obtained a mean value of $52.4 \mathrm{mg} \mathrm{DAP} / \mathrm{g}$ TN. The proportion of TAN in the total $\mathrm{N}$ of rumen bacteria is usually about 0.8 (Smith, 1969) and so the value of $52.4 \mathrm{mg} / \mathrm{g}$ is equivalent to a proportion of 0.0097 DAPN in the TAN (assuming that DAP contains $14.74 \% \mathrm{~N}$ ). Purser \& Buechler (I966) also determined the concentration of DAP in a variety of rumen bacteria and obtained values equivalent to between 0.0074 and $0.0313 \mathrm{~g} \mathrm{DAPN} / \mathrm{g}$ of TAN respectively. The over-all mean value obtained in this experiment was 0.0117 , which is in good general agreement with the previous findings.

The mean over-all proportions of TBAN and TPAN in the rumen TMAN were 0.55 and 0.45 respectively and these proportions were not apparently altered by an increased dilution rate. In calculating these values the contribution of any endogenous rumen amino acid- $\mathrm{N}$ 
has been ignored. The literature contains relatively little quantitative information on the relative contributions of bacteria and protozoa to the microbial $\mathrm{N}$ in the rumen, but Hungate et al. (197I) using sheep given lucerne, estimated that the value for bacterial $\mathrm{N}$ : protozoal $\mathrm{N}$ in the rumen was $54: 46$. Their estimates are in good agreement with the findings of this experiment.

The control treatment induced a mean dilution rate of $0.034 / \mathrm{h}$ and the infusion of saliva increased $\mathrm{D}$ to $0.078 / \mathrm{h}$. With both treatments approximately 0.59 of the protozoal protein within the rumen was retained and only $0.4 \mathrm{I}$ entered the proximal duodenum. Dilution rate is related to mean fluid retention time $\left(T_{\frac{1}{2}}\right)$ by the equation $\mathrm{D}=\log _{n} 2 /\left(T_{\frac{1}{2}}\right)$ (Warner \& Stacy, 1968) and thus a dilution rate of $0.034 / \mathrm{h}$ will give a mean rumen fluid retention time of $20.4 \mathrm{~h}$. However, as only $0.4 \mathrm{I} 2$ of the protozoal protein left the rumen at this dilution rate the effective mean retention time of the protozoa would be $49.5 \mathrm{~h}$. Similarly, the comparable mean retention time for protozoa with a rumen dilution rate of 0.078 would be $2 \mathrm{I} \cdot 7 \mathrm{~h}$. The predominating protozoa in the rumen at both dilution rates were Entodinium sp. which have a division time of approximately $24 \mathrm{~h}$ (Rahman et al. I964), and thus the rumen protozoal population would be only barely maintained at a dilution rate of $0.078 / \mathrm{h}$. Other feeding situations, however, particularly those involving a high intake of forage can produce a faunated rumen with a dilution rate of up to 0.I4 (Harrison et al. 1975; Kennedy \& Milligan, 1978) which would give a mean rumen fluid retention time as low as $5 \mathrm{~h}$. The larger protozoa such as Polyplastron multivesiculatum which are found in the rumens of forage-fed animals have a division time of almost $24 \mathrm{~h}$ (Coleman, I97 I) and their survival at a dilution rate of 0.14 would require that almost $80 \%$ of their population was retained within the rumen. This implies that the proportion of protozoa retained within the rumen may increase markedly at very high dilution rates. In contrast, the high mean rumen retention time of almost $50 \mathrm{~h}$ found with protozoa at a dilution rate of $0.03 / \mathrm{h}$ is almost twice the mean division time of the protozoa and implies a marked recycling of the protozoal protein within the rumen. This recycling would presumably be reduced with increasing dilution rate and could partially explain the increased efficiency of rumen microbial protein synthesis found in vivo when D was increased (Harrison et al. 1975).

Weller \& Pilgrim (1974) fed sheep on maintenance rations of lucerne and wheaten hay and concluded that the flow of protozoal $N$ into the omasum $(0.23 \mathrm{~g} / \mathrm{d})$ was of minimal nutritional significance. Their observations are in marked contrast to the findings of this present experiment in which the mean flow of duodenal TPAN with both treatments $(2 \cdot 18 \mathrm{~g} / \mathrm{d})$ was equivalent to approximately $24 \%$ of the duodenal TMAN, indicating that protozoal amino acids can be an important nutritional component of the $\mathrm{N}$ entering the duodenum of sheep.

The authors would like to thank Professor D. G. Armstrong for all his help and advice and Messrs B. Brown and G. Snowdon for the care of the animals. The surgical preparations were performed by Mr G. F. Brown whose help is gratefully acknowledged.

\section{REFERENCES}

Abe, M. \& Kumeno, F. (1973). J. Anim. Sci. 36, 941.

Beever, D. E., Harrison, D. G., Thomson, D. J., Cammell, S. B. \& Osbourn, D. F. (1974). Br. J. Nutr. $\mathbf{3 2}^{2}$, 99.

Beever, D. E., Thomson, D. J., Pfeffer, E. \& Armstrong, D. G. (I97I). Br. J. Nutr. 26, 123.

Ben-Ghedalia, D., McMeniman, N. P. \& Armstrong, D. G. (1978), Br. J. Nutr. 39, 37.

Boyne, A. W., Eadie, J. M. \& Raitt, K. (1957). J. gen. Microbiol. 17, 414.

Brown, G. F., Armstrong, D. G. \& MacRae, J. C. (1968). Br. vet. J. 124, 78.

Clarke, E. H. W., Ellinger, B. M. \& Phillipson, A. T. (1966). Proc. R. Soc. B r66, 63. 
Coleman, G. S. (1971). Proc. Soc. gen. Microbiol. 6r, 4.

Corbett, J. L., Greenhalgh, J. F. D., McDonald, J. \& Florence, E. (1960), Br. J. Nutr. 14, 289.

Harrison, D. G. (1974). Newsl. app. Nucl. Meth. Biol. Agric. 3, 8.

Harrison, D. G., Beever, D. E., Thomson, D. J. \& Osbourn, D. F. (1973). J. agric. Sci., Camb. 81, 391.

Harrison, D. G., Beever, D. E., Thomson, D. J. \& Osbourn, D. F. (1975). J. agric. Sci., Camb. 85, 93.

Harrison, D. G., Beever, D. E., Thomson, D. J. \& Osbourn, D. F. (1976). J. Sci. Fd Agric. $27,617$.

Harrop, C. J. F. (1974). J. agric. Sci., Camb. 83, 249.

Hungate, R. E. (1966). The Rumen and its Microbes. New York: Academic Press.

Hungate, R. E., Reichl, J. \& Prins, R. (1971). Appl. Microbiol. 22, I 104.

Hutton, K., Bailey, J. F. \& Annison, E. F. (197I). Br. J. Nutr. 26, I 23

Kennedy, P. M. \& Milligan, L. P. (1978). Br. J. Nutr. 39, 105.

Ling, J. R. \& Buttery, P. J. (1978). Br. J. Nutr. 39, 165.

McDougall, E. I. (1948). Biochem. J. 43, 99.

MacRae, J. C. \& Armstrong, D. G. (I969). Br. J. Nutr. 23, 15.

Martin, H. H. (1966). A Rev. Biochem. 35, 457.

Mason, V. C. \& White, F. (1971). J. agric. Sci., Camb. 77, 91.

Minson, D. J. (1966). Br. J. Nutr. 20, 757

Purser, P. B. \& Buechler, S. M. (1966). J. Dairy Sci. 30, 988.

Rahman, S. A., Purser, D. B. \& Tyznik, W. J. (1964). J. Protozool Ix, 5I.

Smith, R. H. (1969). J. Dairy Res. 36, 313.

Stevenson, A. E. \& de Langen, H. (I960). N.Z. Jl agric. Res. 3, 314.

Synge, R. L. M. (1953). J. gen. Microbiol. 9, 407.

Warner, A. C. I. \& Stacy, B. D. (1968). Br. J. Nutr. 22, 369.

Weller, R. A. \& Pilgrim, A. F. (I974). Br. J. Nutr. 32, 34I. 